
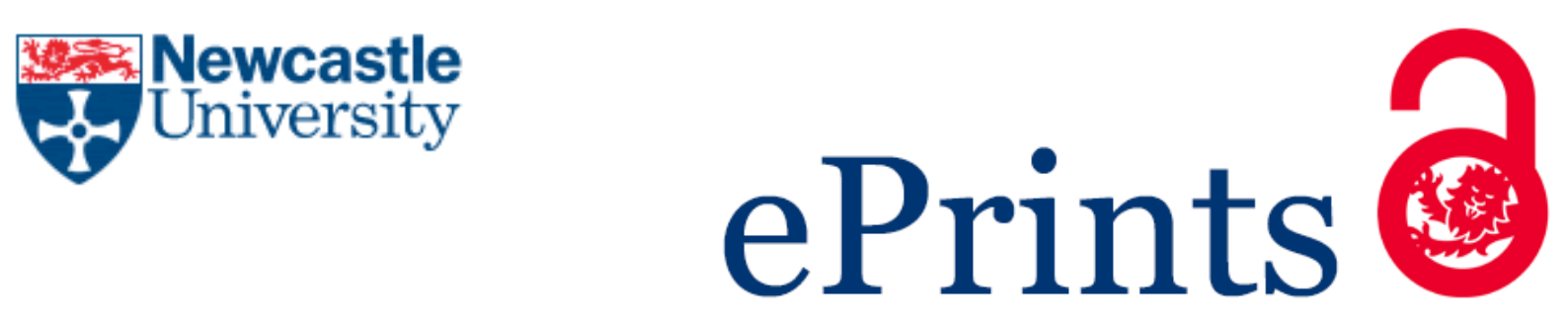

Anderson, F.

Cruising the Queer Ruins of New York's Abandoned Waterfront. Performance Research 2015, 20(3), 135-144.

\title{
Copyright:
}

This is an Accepted Manuscript of an article published by Taylor \& Francis in Performance Research on 23/06/2015, available online: http://www.tandfonline.com/10.1080/13528165.2015.1049047

Date deposited:

$02 / 10 / 2015$

Embargo release date:

23 December 2016

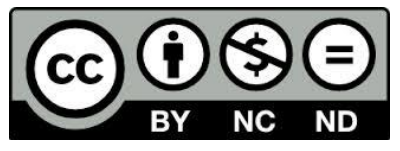

This work is licensed under a

Creative Commons Attribution-NonCommercial-NoDerivatives 4.0 International licence 


\section{Cruising the Queer Ruins of New York's Abandoned Waterfront}

Fiona Anderson

In February 1977, while living in Brooklyn's Red Hook neighbourhood, near the decommissioned New York Naval Shipyard (NYNSY), the artist David Wojnarowicz produced a short poem entitled 'Circulating Drunk to Midnight Music'. By the water's edge, he wrote, wandered 'monks of the dead river' and 'ancient heretics' that 'proposition your image' (Wojnarowicz 1977). They moved through 'street corners' and 'alleyways', 'weary', 'bent and blood-stained' (Wojnarowicz 1977). Wojnarowicz's poem evokes the outmoded Brooklyn harbor of the late 1970s as a bleak and dangerous place-desolate, dystopian and highly erotic, playing with the abstinence that his monastic metaphor implies. Monks and heretics shift 'into delirium ... and curse softly when bodies are set into motion'; '[p]umping organs' bring about 'a flash of holiness.'

To borrow from the novelist Andrew Holleran's description of the Manhattan waterfront 'on summer evenings after dark', the Brooklyn waterfront of the late 1970s was a space both 'vacant' and 'ghostly'-empty, apparently functionless, but with vestiges of an industrious past ([1978] 2001: 79-80). The harbour's long history of corrupt longshoremen's unions and brotherhoods of stevedores are echoed in Wojnarowicz's monastic symbolism. The 'street corners' and 'alleyways' wandered by these men allude to the appropriation of Vinegar Hill, the nearby Sands Street and, later, the Navy Yard, as gay cruising spaces. 'Ancient heretics' propositioned Wojnarowicz's 'image', just as the poet Hart Crane stood, waiting, cruising 'under the shadows by the piers' by the Brooklyn Bridge in the 1920s (Crane [1930] 1958: 4). Two times co-existed in the cruising space of the shadowy waterfront, as they did in Wojnarowicz's photographic series Rimbaud in New York (19789 ), where the artist and three friends posed in turn as the nineteenth-century French poet Arthur Rimbaud in sites around the city that they thought he, as queer, may have been drawn to: porn theatres around 42nd Street, dive coffee-shops on the Lower East Side, the dilapidated subway and the abandoned waterfront. Later Wojnarowicz would be arrested on Brooklyn Bridge, protesting against the passive response of New York City Mayor Ed Koch to the growing human immunodeficiency virus (HIV)/acquired immune deficiency syndrome (AIDS) crisis with the AIDS Coalition to Unleash Power (ACT UP) in March 
1989. Diagnosed HIV-positive in 1987, Wojnarowicz died from complications relating to AIDS in June 1992.

In the years immediately preceding the HIVIAIDS epidemic, Wojnarowicz primarily cruised the abandoned warehouses of Manhattan's Lower West Side waterfront. He wandered there from the storefront art galleries and dance clubs of Manhattan's East Village where he displayed his multidisciplinary artwork-poetry, painting, films, photograph, performance-to the borough's waterfront ruins in search of solitude, creative inspiration and sex. In decline since federal crackdowns on the harbour's Mafia apparatus in the mid1950s and the rise of air transportation in the 1960s, buildings on the once-bustling Hudson River waterfront sat, ostensibly, empty, and fell into ruin. Cruising men, Wojnarowicz recalled in an interview with the curator Barry Blinderman in 1990,

filled every room, half the ceiling fallen in and they stopped carefully around charred beams and rusted metal and glass-a guy here or there with shorts down around ankles playing with his hard cock or getting fucked by someone else..'

Wojnarowicz documented his erotic experiences there in journal entries, poems, photographs, films and graffiti. He depicted the derelict piers as busy 'sexual hunting grounds ... as far away from civilization as [one] could walk' (Blinderman 1989: 54). In a journal entry from 1978, he described the waterfront as a place where 'times [sic] passage becomes irrelevant.' When cruising there, '[o]ld images race back and forth ... [sic] The streets were familiar more because of the faraway past than the recent past.' In this article, I explore Wojnarowicz's cruising in the ruins of the abandoned Lower West Side waterfront and his sense of the peculiar timefulness of the piers, their queer temporality, where images of past and present raced 'back and forth' incoherently. I examine the visual culture of the waterfront and its cruising scene using, primarily, photographs, and other artworks and writings by Wojnarowicz and others as my guide, following their interest in the erotic appeal of ruins and the 'traces of time embedded' in these derelict buildings.

The ruined waterfront, as depicted by Wojnarowicz and his contemporaries, is akin to a Foucauldian heterotopia, made up of 'slices of time' that are not incongruous with its changing functions and its slide into ruination, but instead contingent upon it-'juxtaposing in a single real place ... several sites that are in themselves incompatible' in chronological terms, but providing an aperture on to multiple temporalities, past and present. Equally, 
there is much in Wojnarowicz's writings about the cruising site of the piers and in photographs of the space by his friends and contemporaries-photographers such as Peter Hujar, Alvin Baltrop and Leonard Fink - that resonates with the recent critical and curatorial turn towards ruins, characterized by exhibitions such as 'Ruin Lust' at Tate Britain (2013), and by the increasing online presence of so-called 'ruin porn'. It is not my intention here to lust after ruins metaphorically. Rather, I would like to take the idea of 'ruin lust' beyond its metaphorical invocation, to explore how ruins were sites of a more literal kind of lust in this 'pre-AIDS moment' of the late 1970s. I consider how this approach to ruins may transform the ways in which we conceive of this period, often viewed through ancient ruinous metaphors as a 'last days of Rome,' its liberatory eroticism marked in popular conservative discourse as excessive and self-destructive. For the writer Andrew Sullivan, this was 'the Faustian bargain of the pre-AIDS closet.' Fundamentalist Christian evangelists such as Tim LaHaye, Jerry Falwell and Pat Robertson decried the proliferation of gay cruising cultures in the 1970s and HIVIAIDS in the 1980s symptomatic of impending apocalypse.

Looking at photographs of the cruising sites of the abandoned waterfront today, it is difficult to conceive of a time before HIVIAIDS. Our contemporary knowledge haunts these photographs. This is doubled, at least, in a photograph of a waterfront warehouse by the photographer Andreas Sterzing, taken in 1983. Behind the ruined harbour in the foreground stand the Twin Towers of the World Trade Center. While Sterzing aimed to set up a clear contrast between the decaying condition of the warehouse and the robust construction of the World Trade Center, to a contemporary viewer the towers, as the artist Robert Smithson may have it, appear to 'rise into ruin.' They have also disappeared from the architectural landscape of lower Manhattan. It is difficult to establish or maintain a linear temporal connection between the piers and the towers, and a past and present viewer. For Tim Edensor, ruins are 'symbolic of the inevitability of life passing, of a future in which obsolescence was certain and the inexorable processes of nature dispassionately took their toll of all things.' Ruins, he argues, prefigure 'imminent degeneration and collapse.' Against Edensor, I explore how the ruins of the piers, seen now through photographs and in archival materials, function presently as a means of figuring the early years of HIVIAIDS in New York and its pre-history through a rhetoric different from that of 'degeneration and collapse'.' By turning to the treatment of this ruined place in waterfront work from the pre-AIDS era, placing the past and present of the piers and the queer lives that they hosted in a non-linear open-ended dialogue with each other, we may escape the 
unexpectedly homophobic causality that contemporary 'ruin lust' and the idea of this late1970s moment as a 'last days of Rome' both seem to point to.

\section{Cruising the piers}

Following an increase in police raids of popular cruising sites-public parks, bathhouses and gay bars in Greenwich Village-under Robert Wagner's mayoralty in the lead-up to the 1964 New York World's Fair, men moved towards the water. Cruising encounters occurred there, first inside empty haulage vehicles adjacent to the warehouses-known as the 'trucks'-that were routinely left unlocked at night. The novelist Samuel Delany, in his memoir The Motion of Light in Water (1988), remembered moving through a landscape of 'waist-high tires', the parked trucks forming 'van-walled alleys' in the darkness, lit by the occasional cigarette. Neither industrially active nor redeveloped, by the early 1970 s the piers were effectively outside civic jurisdiction. After the collapse of a portion of the West Side Highway in 1973, they were generally accessible only on foot or by bike. Douglas Crimp noted in some of his recent writing on Lower Manhattan in the later 1970s that the collapsed roadway remained, unreconstructed until the late 1980s, 'as a ghostly barrier between "civilized" Manhattan and the Hudson River.' The piers sat close to gay bars, many leather or Western-themed, along West Street, such as Keller's Bar and The Ramrod, which had opened up in the years after the riots at the nearby Stonewall Inn in the summer of 1969. Many were former longshoremen's saloons.

John Rechy, in the opening chapter of his novel Rushes (1979), described West Street bar country and the waterfront as a 'battered landscape' of 'implied violence' on the edge of 'civilised' Manhattan. The streets leading up to the harbour were, he wrote,

populated only by men, homosexual men; only men, hundreds ... men standing mutely on corners or pressed against buildings darker gray than the sky, or, others, torsos stripped, leaning out of windows, or shoved in clusters against shaded doorways along the crooked streets..'

For Andrew Holleran it was 'a sordid, distorted, poignant place.' He wrote of it in highly romantic terms as a 'place of peculiar magic.' The pull of the piers was such that clubs inland sought to recreate its ruined character. A hollow truck was installed on the top floor of the bathhouse Man's Country. A club on Perry Street took the name The Ruins. Twelve 
West, a members'-only disco venue on West Street, was renamed The River Club in the early 1980s and boasted in flyers of excellent views of the adjacent piers, including their final dismantling later in the decade. The piers themselves, however, without entry or membership fees or dress codes and with only cursory policing, although very dangerous at night, frequented by pickpockets and 'gay bashers', offered a distinct and unusually accommodating hybrid of private and public erotic and social space. 'The abandoned and dilapidated industrial piers,' Crimp recalled, 'presented extraordinary opportunities for experimentation and mischief.'

\section{The erotic pull of ruins}

Through the 1970s, the stone piers on the West Side functioned as makeshift parks, where men sunbathed and cruised, and workers from the nearby Meatpacking District ate lunch. Hastily built in the boom years of Manhattan's shipping industry, the wooden warehouses and piers rotted into the Hudson River as wood-eating bugs returned in the wake of its de-industrialization. Casually discarded cigarettes regularly set portions of older warehouses on fire. The structural decay that made the warehouses so dangerous rendered them more appealing cruising spaces: long corridors facilitated wandering; empty door frames provided peepholes; and cracked windows and broken floorboards created accidental glory holes.

Alvin Baltrop's photographs of the Lower West Side cruising scene were revived recently by the art historian and critic Douglas Crimp in Artforum in 2008 and the exhibition Mixed Use, Manhattan' at the Museo Nacional Centro de Arte Reina Sofía (Museo Reina Sofía) in Madrid in 2010. His photographs capture the dilapidated grandeur of the piers and the play of light through metal beams and open doorways. The men depicted are white, African-American and Latino, and of various ages. Sex or cruising is not always immediately discernible. We have to cruise the images for clues. In some images pairs or groups of men are partially obscured behind steel frames or warehouse walls, paralleling the stealthy motions of the cruising act. An image of a shirtless young man peering through a gaping hole in a warehouse wall plays with the notion of the frame and, consequently, of voyeurism and the practice of cruising itself. As we, the viewers, peer at this young man from behind, scouring the frame for the erotic action that he appears to be seeking, we become involved in a kind of cruising ourselves. Other images offer seemingly impossible vantage points on the warehouses' interior spaces, fantasy visions of sex from 
above. Baltrop went to great lengths to work from this perspective, often attaching himself to the ceiling of several warehouses on a makeshift harness, 'watching and waiting for hours.'

[\{figure1\}]

[\{figure2\}]

The art historical value in Baltrop's cruising photographs goes beyond a formal reading of their compositional features. Baltrop also documented other, important artistic appropriations of the Lower West Side waterfront, which coincided with its erotic acquisition. The inclusion of Baltrop's photographs in 'Mixed Use, Manhattan' put them on a par with better-known works that only alluded to the appropriation of the waterfront as a cruising space, such as Willoughby Sharp's curatorial project at Pier 18 (1971), which also appeared in the exhibition at the Museo Reina Sofía in 2010. John Baldessari's 'Hands Framing New York Harbor' appears, a-chronologically, different from the vantage point of Baltrop's 'framed' cruising images. The leather-bound cruisers that Baltrop photographed seem to suggest that we take a second look at ' 9 at Leo Castelli,' curated by Robert Morris at Castelli's waterfront warehouse further uptown in December 1968, perhaps in the light of Morris's own formal interest in the New York gay leather scene. Both Baltrop's photographs and these earlier examples of artistic appropriations of the Lower West Side waterfront, as well as photographs of waterfront work by Wojnarowicz, appeared in 'The Piers: Art and sex along the New York waterfront,' an exhibition at the Leslie-Lohman Museum of Gay and Lesbian Art in New York in 2012.

Baltrop's photographs of the derelict piers also provide invaluable documentation of Gordon Matta-Clark's gargantuan waterfront work 'Day's End' (1975). We see the 'S\&M cruisers' that Matta-Clark maligned in letters to friends about his work inside it, responding to the new patterns of light and shadow that the cutting generated, transforming its potential as a cruising space. Lee described Matta-Clark's intervention as, like much of the artist's other work, offering a commentary on its decline, 'structurally coincidental with the building's historical passage into outmodedness, illuminating the twilight of the pier itself'. Viewing Baltrop's photographs of Matta-Clark's work, now, illuminates multiple twilights: the industrial decline of the harbour, the imminent erasure of Matta-Clark's illegal intervention, the forthcoming disappearance of a particular sexual culture. In light of this, Baltrop's photographs also, unwittingly, allude to Matta-Clark's own untimely death from pancreatic cancer in 1978. Revived after these multiple deaths, including the photographer's own in 2006, Baltrop's waterfront photographs cut into the received 
chronology of the degenerating piers. As Pamela Lee noted in her biography of MattaClark, published prior to the rediscovery and revival of Baltrop's work, in the co-mingling of the artist's life and his work 'pastness and presentness collide so that nostalgic longing and historical distance refuse any easy distinctions'. At the Ward Line Pier Project, a vast, but casual, artistic initiative organized by David Wojnarowicz and the artist Mike Bidlo at a former Ward shipping line pier at the end of Canal Street in 1983, the artist John Fekner spray-painted a stencilled tribute to Matta-Clark on the exterior of the warehouse and made a tiny cutting, in homage to Day's End, on an upstairs window. Like Matta-Clark's own cuttings and Baltrop's photographs of them, these are complexly nostalgic works that, posthumously, in two senses, reflect the waterfront's own decline and decay.

Waterfront buildings stripped of their original purpose were the ideal location for anonymous sexual encounters, since they encouraged the projection of phantasy, distinct from the ordinary urban time-space of work, public transport and apartment buildings. Time, there, was also in ruins. In Peter Hujar's photographs of the Canal Street pier in the early 1980s, such as Pier-Four Doors (1981), the multiplicitous doors offer no spatial or temporal direction. They also encourage visual cruising. In their ineffectuality, they direct our gaze towards the peeling animation of the rotting walls. Accidental orifices have developed on almost every surface, revealing the underlying structure of the warehouse or only darkness. Above, light pours in from a hole in the ceiling, illuminating graffitoed texts on the crumbling wall. Similarly, throughout the Ward Line pier, captured in photographs by Hujar and the German photographer Andreas Sterzing, the proliferation of graffiti and other ephemeral artworks adds an aesthetic quality and a sculptural dynamism to the peeling walls and rotted holes of the building's structure, formed and fostered by neglect and chance.

Appearing closer to 'the faraway past than the recent past', for Wojnarowicz and his friends, the piers were Pompeii-esque. Filled with erotic murals by the artists Luis Frangella, Tava and Keith Davis, a designer for Artforum, they seemed to have more in common with distant ruined places than with the city they fringed (fig. 6). The filmmaker Ivan Galietti drew a similar comparison in his film Pompeii New York, which sought to detail 'the ravaged beauty of this landmark of alternative lifestyles', on an adjacent pier, in 1982 (IGIC Archive 1982). It featured a cameo from David Wojnarowicz. The comparison with the erotic culture of Pompeii was a timely one, as the ill-fated Roman town occupied a special position in the popular American imagination of the 1980s, regularly invoked by 
politicians and cultural commentators as a metaphor for the appearance and spread of HIVIAIDS.

In the introduction to the television mini-series The Last Days of Pompeii (1984), based on Edward Bulwer-Lytton's 1834 novel of the same name, a voiceover proclaims Pompeii a 'byword for excess and indulgence, and dedication to the pursuit of pleasure... renowned for its works of art, its thriving commerce, but notorious for its licentiousness.' In an interview with Playboy magazine in the same year, the actress Joan Collins drew similar connections: 'Herpes and AIDS have come as the great plagues to teach us all a lesson. It's like the Roman Empire. Wasn't everybody running around just covered in syphilis? And then it was destroyed by the volcano'. Galietti, in contrast, described his film as an effort 'to recreate that atmosphere of men moving in the half-light, in this distant night world on the Manhattan shore ... to suffuse it with the sexuality of the frescoes and taboos', to record the demise of 'a surreal monument, half-destroyed, bathed in strange light, a poetical', 'post-Vesuvian' ruin'. Alluding simultaneously to the supposed sexual excess of Pompeii and its destruction, half-lit and 'half-destroyed', Galietti's depiction of the ruined waterfront as Pompeii-esque set it outside of normative time, permitting the piers to exist in both 'the faraway past' and 'the recent past', refiguring the homophobic causality of these latetwentieth-century visions of Pompeii by rejecting historical linearity.

In a drawing from one of Wojnarowicz's unpublished journals, entitled Thug Obscured, a stubbled 'thug' stands before rotting wooden pier pilings and beside a distant New Jersey factory, spewing smoke. His face is 'obscured' by black lines that parallel the smoke from the adjacent factory. Importantly, these appear as later additions to the work, like the mental image of a face fading from memory's view. Similarly, the 'thug's' shirt blends into the blue of the water; he returns to the river or, perhaps, has emerged from it. In the alsounrealized Waterfront Thug series, studies for which appear in the same journal, Wojnarowicz removes the face entirely. The torso, Wojnarowicz planned, would be accompanied by photographs of waterfront buildings, images of the piers rather than the men who cruised there, which would be placed underneath, extending into the crotch of the depicted 'thug'. The factory chimneys become phallic, a connection that Fassbinder made in his 1982 film of Jean Genet's novel Querelle de Brest (Querelle of Brest) (1947), about murderous sailors in a northern French port town. The thug's musculature draws on the bodies of men whom Wojnarowicz met at the waterfront and wrote of extensively in his journals, recalled from phantasmic memory. It was informed also by the photographer 
Lewis Hine's photographs of workmen, including longshoremen, from the 1930s, which Wojnarowicz glued into this same journal. In Cruising Modernism: Class and sexuality in American literature and social thought, Michael Trask examines the queer intimacy of dockworkers that Hine's work points to, of people living and working at sea, away from family, or in casual labour arrangements, outside of normative temporal and social markers. As he had done with his Rimbaud in New York series, Wojnarowicz activated the homoeroticism of Hine's images of labourers by making them present, pairing them with images of the cruising spaces of the ruined harbour. The erotic aspect of these images of faceless men, for Wojnarowicz, was site-specific.

Anonymous sex activated these past narratives of the waterfront. Alternate times were conjured through the act of cruising in this place. 'Restless walks' through Manhattan to the West Side piers, Wojnarowicz wrote, left him 'filled with coasting images of sights and sounds ... that roll up and funnel in like some secret earphone connecting me to the creakings [sic] of the city'. He was reminded 'of sailors, of distant ports'. Faceless, anonymous 'toughs' were appropriated, too, as literary figures from Wojnarowicz's own desiring imagination, writers that he read and that his own writing was informed by. One man, with 'a tough face, square-jawed and barely shaven, tight-cropped hair, wiry and black, intensely handsome' was like the American professional boxer Rocky Marciano or the Russian Futurist poet Vladimir Mayakovsky, who visited New York in the 1920s, and others resembled Genet. In a journal entry from 1979, Wojnarowicz linked his own interest in the sexual charge of buildings with the architectural eroticism of Genet's sole film work Un Chant d'Amour (A Song of Love) (1950), after going home with a man he met in 'the shadows of the night pier, who looked like Genet. In the film, two prisoners in adjacent cells create fantasies about the other, which are played out through inventive, semionanistic gestures: the sharing of a cigarette through a crack in the wall between them. Like the holes that emerged in the decaying warehouses on the Manhattan waterfront, the prison wall is anthropomorphized as a bodily orifice, embedded with traces of its habitation by sailors and dockworkers, and the dilapidated window adopts an important voyeuristic purpose.

For Rechy and Wojnarowicz, the waterfront was animated by an eroticism that exceeded its appropriation by cruising men and the leather and Western sexual cultures of the bars. It seemed to emerge from the physical form of the harbour, emanating from the ruined buildings themselves, rather than from their later sexual mis-uses. These were lustful 
ruins. In Wojnarowicz's visual and textual renderings of this cruising site, the waterfront's appeal as a sexual space was inextricably linked to the architecture itself. In an unpublished poem from 1979, 'Dream of Federico Fellini/Pasolini', Wojnarowicz wrote of male bodies, cruising, in motion, as 'curving their bodies along' the walls of a Roman coliseum, and of the warehouses and piers as 'late night walkways where history strolls'. In 'End Street', cruising men 'among the loading docks of shipyards' were likened to 'pillars', like the rotting pier footings that punctuated the Hudson shore. These poetic visions were made possible by the ruination of the buildings themselves, generating ghosts as they, too, slipped into obsolescence and disappeared. In Rechy's Rushes, sexually charged glances at fellow cruisers produce what he called a unique 'sextime' [sic] through which men appear as 'young ghosts haunting the streets', and in which the city presents itself, in bodily terms, as a 'cadaver', the piers its 'rotted gut'. Living men became spectral as the buildings became bodily.

As Laud Humphreys noted in Tearoom Trade (1975), his ground-breaking study of male cruising in public toilets, 'these men seem to acquire stronger sentimental attachments to the buildings in which they meet for sex than to the persons with whom they engage in it'. Cruising men and cruising spaces appear indivisible. In John Rechy's fictive descriptions, travelling through the warehouses parallels the repetitious thrusts of the sexual act itself, and he makes even more explicit the role of the crumbling architecture of the waterfront as a prop in the sexual encounters that took place there. As Endore, the central character in $\underline{\text { Rushes, }}$ cruises the riverside, he focuses not on other men, but on '[i]ron, steel, cement, the buildings ... shoving himself in and out of them to become a part of their ordered patterns'. Wojnarowicz's and Rechy's allusive comparisons of industrial architecture and gay sex recall Robert Smithson's description of temporarily obsolescent machinery in his essay 'A tour of the monuments of Passaic Jersey,' first published as 'The monuments of Passaic' in Artforum in 1967, and reprinted in his collected writings (1979). A large pipe, Smithson speculated, looked as though it 'was secretly sodomizing some hidden technological orifice'. 'A psychoanalyst', he notes briefly and facetiously, 'might say that the landscape displayed "homosexual tendencies". Smithson seems to mock the functionless machinery, as it 'rises into ruin', by drawing connections between defunct industrial spaces and the non-reproductivity of gay sex, its failed sexual economy, what Smithson calls its 'abandoned sets of futures'.

For Wojnarowicz, Rechy, Hujar and Baltrop, the ruins of the piers were embodied spaces 
because of the past functions and uses they held traces of. Instead of the arguably homophobic implications of Smithson's description of the 'homosexual' riverside landscape of Passaic, we may see the similarly defunct piers of Manhattan's Hudson River waterfront, in their multiplicity, instead as a queer space, always 'ruined'. As Judith Butler asserted in the closing chapter of Bodies that Matter: "[i]f "queer" is to be a site of collective contestation, the point of departure for a set of historical reflections and future imaginings, it will have to remain -in the present'-like the derelict waterfront itself_-'that which is never fully owned, but always redeployed, twisted, queered from a prior usage'. Cruising at the queer space of the piers, as Wojnarowicz's work demonstrates most readily, was a cross-temporal collaboration with its former inhabitants made possible by the cumulative architectural memory of the piers and warehouses. In Wojnarowicz's depictions of sex at the waterfront, alternate times were accessible through cruising, through physical contact, however fleeting, with the phantasmic or spectral body of another, what medieval historian Carolyn Dinshaw has described as a 'queer historical touch'. A sucking or fucking in a waterfront warehouse offered a point of entry to an eroticized industrial or maritime past, apart from the economy or temporality of the contemporary city, or also perhaps to an entirely phantasmic co-mingling of poets and artists, dead and alive, outside of time or dead to it. Multiple temporalities coexisted there idiorrhythmically, living together but apart, as in a monastery, hosting these 'monks of the dead river'.

The value of these waterfront ruins for rethinking 'the pre-AIDS moment' is not that they provide contemporary scholars and viewers with a metaphor for thinking about the ruination of diseased bodies or that they emphasize an earlier queer sexual culture in evitable decay, but that they provide us with a means of visualizing sexual liberation beyond the homophobic causal relation between cruising and the development of HIVIAIDS articulated by Sullivan, Robertson and others. Time did not overlap there and then; at least two time periods coexisted. Normative distinctions between time periods or generations, between past and present, had, as Wojnarowicz observed in his early visits to the piers, 'become irrelevant', unmoored from a normative linear connection. In Wojnarowicz's, Rechy's and Baltrop's work, the erotic bodily metaphor of the ruin takes the question of 'the pre-AIDS moment' outside of time and thus beyond causality. Their work provides contemporary viewers with an idiorrhythmic means of ridding the late 1970s of the sense of historical and viral momentum generated by ruinous Roman analogies. Their work on ruins stimulatess instead the pleasures of looking back, of cruising the abandoned spaces and 'sets of futures' of the late 1970s. As we look for glances towards us, seeking historical connection, we find only flotsam, washed up unexpectedly in journal entries, 
poetry and photographs, upon the ruins of the recent past.

\section{Bibliography}

Butler, Judith (1993) Bodies that Matter, New York: Routledge

Carr, Cynthia (2012) A Fire in the Belly: The Life and Times of David Wojnarowicz, London: Bloomsbury

Castiglia, Christopher and Christopher Reed (2011) If Memory Serves: Gay Men, AIDS, and the Promise of the Queer Past, Minneapolis: University of Minnesota Press

Crane, Hart (1958) 'Proem: To Brooklyn Bridge' [1930], The Complete Poems of Hart Crane, Garden City, NY: Doubleday, pp. 3-4

Crimp, Douglas (2008) 'Alvin Baltrop: pier photographs, 1975 - 1986,' Artforum, pp. 262-273

Delany, Samuel (1988) The Motion of Light In Water, New York: Arbor House

Dinshaw, Carolyn (1999) Getting Medieval: Sexualities and Communities, Pre- and Postmodern, Durham, NC: Duke University Press

Edensor, Tim (2005) Industrial Ruins: Space, Aesthetics, and Materiality, Oxford; New York: Berg

Freeman, Elizabeth (2007) 'Introduction' GLQ: A Journal of Lesbian and Gay Studies Volume 13, Number 2-3, pp. 159-176

Gardner Coates, Victoria C., Kenneth Lapatin, and Jon L. Seydl (2012) The Last Days of Pompeii: Decadence, Apocalypse, Resurrection, Los Angeles: Getty Publications

Foucault, Michel (1986) 'Of Other Spaces,' Diacritics, Vol. 16, No 1, pp. 22-27

Hayden, Dolores (1997) The Power of Place: Urban Landscape as Public History, Cambridge, MA; London: MIT Press

Holleran, Andrew (2001 [1978]) Dancer from the Dance, New York: Harper Perennial

Holleran, Andrew (1983), 'Nostalgia for the mud' in Denneny, C. Ortleb, \& T. Steele, eds., The Christopher Street Reader: Journalism from America's Leading Gay Magazine, London:

Chatto and Windus, pp. 67-70

Humphreys, Laud (1975) Tearoom Trade, Chicago: Andine Publishing Company

Lee, Pamela M. (1999) Object to be Destroyed: The Work of Gordon Matta-Clark, Cambridge, MA: MIT Press

Long, Thomas L. (2012) AIDS and American Apocalypticism: The Cultural Semiotics of an Epidemic, New York: State University of New York Press

Pompeii New York at the Pyramid Club (1982) flyer [ephemera] International Gay Information Center (IGIC) Archive, Section VI: Ephemera, Bars; New York Public Library, New York 
Rechy, John (1979) Rushes, New York: Grove Press

River Club (1983) flyer [ephemera] International Gay Information Center (IGIC) Archive, Section VI: Ephemera, Bars; New York Public Library, New York

Ruins (no date) flyer [ephemera] International Gay Information Center (IGIC) Archive, Section VI: Ephemera, Bars; New York Public Library, New York

Scholder, Amy, ed. (1999) In the Shadow of the American Dream: The Diaries of David Wojnarowicz, New York: Grove Press

Smithson, Robert (1967) 'A Tour of the Monuments of Passaic,' Artforum, pp. 52-57

Sullivan, Andrew (1996) 'When Plagues End: Notes on the Twilight of an Epidemic,' New York Times Magazine, pp. 52-62, 76-77, 74.

Trask, Michael (2003) Cruising Modernism: Class and Sexuality in American Literature and Social Thought, London and Ithaca: Cornell University Press

Wojnarowicz, David (1989) 'Biographical Dateline', in Blinderman, B (ed), David Wojnarowicz: Tongues of Flame, New York: Distributed Art, pp. $113-119$

Wojnarowicz, David (1991) Close to the Knives: A Memoir of Disintegration, New York: Vintage

Wojnarowicz, David (1977) Circulating Drunk to Midnight Music [manuscript] David Wojnarowicz Papers, Series 3, Subseries A, Box 5, Folder 142; Fales Library and Special Collections, New York University Libraries.

Wojnarowicz David (1979-80) 1979-80: NY [manuscript] David Wojnarowicz Papers: Series 1, Box 1, Folder 12; Fales Library and Special Collections, New York University Libraries.

Wojnarowicz, David (1978) 1978: NY/France [manuscript] David Wojnarowicz Papers: Series 1, Box 1, Folder 5; Fales Library and Special Collections, New York University Libraries.

Wojnarowicz, David (1980) New York 1980, Feb. 2 - April 3 [manuscript] David Wojnarowicz Papers, Series I, Box 1, Folder 13; Fales Library and Special Collections, New York University Libraries. Also available at http://dlib.nyu.edu/findingaids/html/fales/woj/dscref11.html. Accessed $2^{\text {nd }}$ March, 2015.

Wojnarowicz, David (1979) 1979: NYC, Jun 6 - Aug 28 [manuscript] David Wojnarowicz Papers: Series 1, Box 1, Folder 11; Fales Library and Special Collections, New York University Libraries

David Wojnarowicz Papers, Series I, Box 1, Folder 11, Title: New York - June 6, 1979 to August 28, 1979; Fales Library and Special Collections, New York University Libraries 